puterized communications will have to be developed between UCCA, the examining boards and the universities.

Another scheme for assisting and quickening the selection procedure is the use of an aptitude test. Together with the opinion of a head teacher and a university interview, this would provide a valuable assessment of a candidate's ability and suitability. A pilot scheme along these lines is now being carried out by the Committee of Vice-Chancellors and Principals of the United Kingdom, with the co-operation of the central council.

\begin{tabular}{|c|c|c|}
\hline \multirow[t]{2}{*}{ Subject } & \multicolumn{2}{|c|}{$\begin{array}{l}\text { Total candidates through } \\
\text { UCCA, October } 1966 \text {, by } \\
\text { order of first preference : }\end{array}$} \\
\hline & Applied & Accepted \\
\hline Education & 654 & 148 \\
\hline $\begin{array}{l}\text { Medicine, dentistry and } \\
\text { health }\end{array}$ & 8,255 & 2,434 \\
\hline Engineering and technology & 13,686 & 7,677 \\
\hline $\begin{array}{l}\text { Agriculture, forestry, } \\
\text { veterinary science }\end{array}$ & 1,975 & 896 \\
\hline Pure science & 18,306 & 12,850 \\
\hline $\begin{array}{l}\text { Social, administrative, } \\
\text { business studies }\end{array}$ & 24,882 & 9,533 \\
\hline $\begin{array}{l}\text { Architecture, and other } \\
\text { professional and vocational } \\
\text { subjects }\end{array}$ & 2,049 & 485 \\
\hline $\begin{array}{l}\text { Language, literature, area } \\
\text { studies }\end{array}$ & 13,181 & $6, \tilde{5} 09$ \\
\hline Arts other than languages & 7,633 & 3,986 \\
\hline Total & 90,952 & 44,526 \\
\hline
\end{tabular}

\section{UNCTAD in Tatters}

Tre second United Nations Conference on Tariffs and Trade, just completed in New Delhi, was heralded with such gloomy predictions that little was expected of it. In the event, even less seems to have been achieved. The conference ended with the admission that little had been done to bridgo the widening gap between rich and poor. Some last minute sessions did manage to salvage something from the ruins, in the form of several agreed statements, but these are so feebly expressed and hedged about with conditions as to make them nearly useless. There now seems to be a real danger that the underdeveloped countries will decide to wash their hands of the West, and may even perhaps go as far as to cancel their debts and decide that they can do better on their own.

The fundamental problem seems to have been that the Western countries had nothing to offer. Under the pressure of unfavourable external balance of payments and a disenchantment with aid, the United States, Britain and France have all reduced their aid this year. (Aid from Britain, though constant in sterling terms, will fall because of devaluation.) In this situation, it was impossible that the demands of the developing countries could be met, although the president of UNCTAD, Dinesh Singh, did have a good word to say for the socialist countries of Eastern Europe.

Two things were decided at New Delhi. First, after a lengthy discussion, it was agreed in principle that the aid given by developed countries should represent one per cent of their gross national products. The alternative, based on one per cent of the national income, is a lower target. So the final decision does set slightly higher targets, although it sets no date for these to be reached. France favoured the change to the new target, in part, it seems, because its own aid is more generous than other countries, and it finds more ambitious standards less embarrassing than other countries do.

The conference also agreed in principle to give preferences to manufactured products from developing countries. But the agreement excludes manufactured agricultural products, and the United States also wishes to exclude textiles from the agreement. The United States also made agreement conditional on French agreement to give up its existing preferences with developing countries. The idea of supplementary financing, to help countries whose external balances are hit by the fluctuating prices for commodities, seems to have survived the conference, but not to have made much progress. The scheme, originally put forward by the UK and Sweden at the first UNCTAD meeting, was opposed by France. The communiqué says little on the subject, but does agree to keep in being the inter-governmental group which is studying the problem.

The secretary-general of UNCTAD, Dr Raul Prebisch, now hopes that a ministerial meeting on aid will be held in 1969. By that time, perhaps, the climate could be more favourable. But Dr Prebisch will be very lucky if he can recoup in 1969 the loss of goodwill which seems to have been suffered at New Delhi. The British position will at best be only on the mend, and the United States is unlikely by then to have repaired entirely its balance of payments deficit.

\section{Inadequate Training}

SOME rather startling criticisms of teacher-training courses for chemistry graduates appear in a recent publication compiled by the British Committee on Chemical Education, sponsored jointly by the Royal Society and the Royal Institute of Chemistry (price $3 s .6 d$.). It brings out that there is not only a marked difference between the recognized priorities and needs of the teachers and the actual courses and facilities provided for them, but that topics relating to the teaching of chemistry are not adequately studied either in education institutions or during teaching practice.

These criticisms are drawn from replies to questionnaires sent out by the committee with the aim of obtaining from university departments of education and colleges of education in the United Kingdom information about their courses and training. A second aim was to obtain from practising graduate teachers of chemistry their opinion of the type of teacher-training studies that would be most useful to them.

The last time an inquiry of this sort was carried out was in 1959 when the Association for Science Education appointed a subcommittee of practising school teachers, lecturers in university departments of education, and lecturers in colleges of education to investigate the training of science teachers. At the time it was concluded that the facilities, both in time and in accom. modation for practical work, were quite inadequate. A number of the issues which emerged during the association's inquiry emerged again in the recent study. Out of 130 replies from experienced teachers in 
schools, many were critical of the courses they had followed in university education departments in relation to subsequent work in schools. 28 per cent of them thought that the history of education was useless as part of their conventional course, and a further 50 per cent maintained that it was of little value. 94 per cent of the teachers considered that guidance relating to their own subject was of the utmost importance, but recognized the importance of educational psychology and the aims of education as well. More than 80 per cent of teachers thought that methods of teaching conceptually difficult topics, lesson planning and the aims of chemistry teaching deserved a lot of attention.

Answers to a second questionnaire scnt to teachers who had trained in 1965-66 were equally critical. Little attention was given during teaching practice to several topics considered important, and there was rarely any opportunity during teaching practice for many to receive advice from experienced teachers before, after or during lessons. Furthermore, many students were unable to try out class experiments and demonstrations before lessons during teaching practice. The committee suggests that, in view of the short time allotted in many universities to chemistry teaching, coupled with the marked lack of laboratory space and equipment in many of the departments, students often do not have an opportunity to consider these matters. The nature and content of training courses see $m$ to have been so unsatisfactory that between 1955 and 1965 a substantial number of graduates may have decided against undertaking training for this very reason.

The committee considers that university departments of education try to cover too wide a range of subjects, leading to a superficial treatment which is neither useful nor satisfying to graduates. In view of the short time available for training, fewer subjects should be studied and this requires placing subjects in an order of priority. It also emphasizes the need to astablish some means by which experienced teachers can make known to university departments of educat.ion and colleges of education those aspects of study, guidance and training which in their experience would be of greatest value to teachers in the realities of school work. Better provision of laboratories is another recognized need during training.

\section{Tax on Teaching}

The announcement by the Chancellor of the Exchequer in the British budget of increased purchase tax on projectors and tape recorders seems to be producing confusion as well as complaint. At first sight the 50 per cent tax on projectors and 33.3 per cent on tape recorders looks simple enough, but what of teaching machines? No direct mention of them was made in the budget speech; the Inland Revenue declare that no exemption has been stated for them, and that "viewers" are included in the new tax; but ESL, one of the largest manufacturers in Britain of teaching machines, has not yet been told by the Customs and Excise to put up its prices. In the meantime the manufacturers, through their association, BEAMA, have stated their case to the Ministry of Technology and the ministry is in turn making representation to the Treasury.

If prices do rise, local education authorities will be forced to cut down their orders, as allocations are usually for a set sum of money rather than a certain number of machines. Thus a tax on teaching machines will result in money being transferred from one government purse to another, with schools and universities the suffering intermediates. The Association of Education Committees has therefore taken the matter up with the Department of Education and Science and the department is discussing it with the Treasury.

Just what effect this purchase tax would have on education is difficult to estimate. Bodies like the National Centre for Programmed Learning in Birmingham are trying to swell to a flood the trickle of people using audio-visual aids. At present the centre estimates that only five per cent of schools use programmed learning. Equipment is already expensive, and a tax increase now might turn the tide in the other direction. Books are one alternative to electro-magnetic machines for programmed learning, and are likely to be more effective for small budgets. The manufacturers claim that machines are more versatile, take up less space and last longer than books, but there has not yet been time for these claims to be verified. As yet there seems to be no evidence that machine programmes are more effective than books, but they do cover wider ground, in that 70 per cent of the 18,000 programmes available are in machine form.

The National Centre for Programmed Learning is keen to encourage the use of tape recorders and projectors as they are more versatile than conventional "teaching machines", even though work with them is still at an experimental level. It has been shown, for example, that eight-year-olds who cannot read can understand basic scientific concepts which are presented on tape. Machines which are used solely for education purposes could well be exempted from the new purchase tax, but the case of tape recorders and projectors for use in schools is more complicated, as some form of exemption would have to be introduced for educational establishments.

\section{Thames Action}

There was an enthusiastic response to a one-day conference on the River Thames held last Monday, April 1. The conference, sponsored by the Greater London Council in association with the London Boroughs Association, was attended by representatives of the riverside boroughs, the county authorities, voluntary and recreational organizations, professional bodies and commercial undertakings. The conflicting interests of all those concerned with the river were very obvious-at least twenty different authorities have an interest in the 43 miles of the Thames passing through Greater London-but the growing urgency for action may result in constructive co-ordinated planning for the river's future. The very fact that the conference has been held is a step in the right direction. Now there is the machinery for action on a large scale. The Greater London Council has decided, in conjunction with the London Boroughs Association and the other interests, to accept responsibility for the initiation. encouragement and support of action for the improvement of the Thames. A number of schemes are already in the planning stage and some of these were mentioned and discussed at the conference. They included, for example, the redevelopment of the St Katherine 